\title{
Seed Production Potential of Jute (Corchorus olitorius Linn.) as Affected by Integrated Nutrient Management under Irrigated Midland Rice Ecology for Self-sufficiency of Marginal Farmers
}

\author{
Ramprosad Ghosh ${ }^{1 *}$, R.K. Sarkar' ${ }^{2}$ and A.K. Ghorai ${ }^{3}$ \\ ${ }^{1}$ Department of Agriculture, Government of West Bengal, India \\ ${ }^{2}$ Institute of Agricultural Science, University of Calcutta, West Bengal, India \\ ${ }^{3}$ ICAR-Central Research Institute for Jute and Allied Fibres, Barracpore, West Bengal, India \\ "Corresponding author: rpghoshada@gmail.com
}

\begin{abstract}
Jute fibre producing states are completely dependent for its most vital critical input i.e., seed on import from South and West Indian states of India like Maharastra, Andhra Pradesh, Telengana and Karnataka. For self-sufficiency, jute seed production potential of irrigated midlands (0-30 ponding) were tested by developing shallow ridges $(15 \mathrm{~cm}$ high and base width $50 \mathrm{~cm}$ ) on puddled rice soil from Mid-August to January. Scanty rainfall coupled with cool and dry weather from November to January has opened up a new vista for jute seed production in traditional jute fibre producing areas of Eastern India. Jute seed production was recorded highest (635.83 kg/ha) using N: $\mathrm{P}_{2} \mathrm{O}_{5}: \mathrm{K}_{2} \mathrm{O}:: 60: 40: 40 \mathrm{~kg} / \mathrm{ha}$ (Recommended Dose of Fertiliser, RDF) along with bone meal $1.0 \mathrm{t} / \mathrm{ha}$ (23\% more over control). In control (RDF) the jute seed production potential was only $518.33 \mathrm{~kg} / \mathrm{ha}$. The RDF along with jute leaf manure @ $0.5 \mathrm{t} / \mathrm{ha}$ produced 542 $\mathrm{Kg}$ jute seed/ha (5\% more over control). Combination of recommended fertiliser and Neem cake @ $0.2 \mathrm{t} /$ ha produced $580 \mathrm{~kg}$ jute seed/ha (11.89\% more over control). Amongst sole chemical fertiliser treatments, treatment $\mathrm{T}_{3}\left(\mathrm{~N}: \mathrm{P}_{2} \mathrm{O}_{5}: \mathrm{K}_{2} \mathrm{O}:: 100: 40: 40\right)$ produced $579.17 \mathrm{~kg}$ jute seed $/$ ha (12\% more than RDF). Thus, 3.1 to $3.8 \mathrm{~kg}$ jute seed can be harvested from 1.5 cent $\left(60 \mathrm{~m}^{2}\right)$ rice midlands, which is sufficient enough to meet the jute seed requirement of one hectare area, using jute seed drill or jute sowing by regulated broadcast method. Incidentally more than $80 \%$ of jute farmers are small and marginal in nature and they grow jute in less than one hectare area. RDF+ jute leaf manures @ 0.5 to 1.0 t/ha recorded higher net returns ( $₹ 28600$ to $₹ 32800 /$ ha) owing to its low cost of production and relatively higher seed yield over RDF alone in both the years with higher $\mathrm{B}: \mathrm{C}$ ratio from 1.56 to 1.63. Application of augmented chemical fertilization $\mathrm{T}_{2}, \mathrm{~N}: \mathrm{P}_{2} \mathrm{O}_{5}: \mathrm{K}_{2} \mathrm{O}:: 80: 40: 40 \mathrm{~kg} / \mathrm{ha}$ fetched higher net returns ( $₹ 30560$ to $₹ 36510 / \mathrm{ha}$ ) and B: C ratio from 1.58 to 1.70. Thus judicious management can achieve jute seed production in Eastern India and Bangladesh.
\end{abstract}

Keywords: Jute Seed, Integrated Nutrient Management, Recommended Dose of Fertiliser (RDF), Midland Rice Ecology, Ridge and Furrow, Bone Meal, Jute Leaf Manure, Neem Cake

Jute is an important commercial crop of eastern states of India. Although West Bengal occupies about $70 \%$ area and production of jute in the country, jute farmers in this state, grow jute mainly for fibre production rather than for seed purpose. Even though they are sometimes facing acute shortage of quality seeds in the cropping season, they are still dependent on jute seeds from non-jute growing states like Maharashtra, Andhra Pradesh, Karnataka, Telengana etc. Mailk et al. 2013 reported use of quality seeds of an improved variety plays a key role in boosting up jute fibre production.

Jute for fibre is primarily grown in medium $(0-30$ $\mathrm{cm}$ ponding depth in rice season) to low $(>50 \mathrm{~cm}$ ponding depth) lands and the usual jute based cropping system is Jute-rice-vegetables/pulses/ oilseed etc. After jute harvest, the soil becomes waterlogged (0-100 $\mathrm{cm}$ or even more in deep water areas) due to rainfall and jute seed production thus is not possible in traditional jute fibre growing areas. 
Hence there is a need to investigate the feasibility of jute seed production in traditional jute growing areas, integrated nutrient management (INM) again plays a vital roleon quality jute seed production and it will also reduce the production cost maintaining the soil fertility at sustainable level.

A primary report of jute seed production for home scale self-sufficiency has also been made by Ghorai et al. 2008.

Therefore, an attempt has been made to explore the possibility of jute seed production in Eastern India with a view to make self-sufficiency in jute seed production.

\section{MATERIALS AND METHODS}

The experiments were conducted during 2012 and 2013 in medium land of ICAR-CRIJAF North farm in clay soil, having pH 7.3, EC $0.25 \mathrm{dS} / \mathrm{m}$, Available N, P and $\mathrm{K}$ were $374.4,40.6$ and $370.6 \mathrm{~kg} /$ ha respectively. The farm is situated at $22^{\circ} 45^{\prime} 35.28^{\prime \prime}$ North latitude and $88^{\circ} 25^{\prime} 36.84^{\prime \prime}$ East Longitude with an average altitude of 9 meters above mean sea level. The experiment was laid out in complete randomised block design with nine treatments replicated thrice. The treatments were (1) $\mathrm{T}_{1}: \mathrm{N}: \mathrm{P}_{2} \mathrm{O}_{5}: \mathrm{K}_{2} \mathrm{O}:: 60: 40: 40$ $\mathrm{kg} / \mathrm{ha}$ (RDF \& Control), (2) $\mathrm{T}_{2}: \mathrm{N}: \mathrm{P}_{2} \mathrm{O}_{5}: \mathrm{K}_{2} \mathrm{O}:: 80: 40: 40$ $\mathrm{kg} / \mathrm{ha},(3) \mathrm{T}_{3}: \mathrm{N}: \mathrm{P}_{2} \mathrm{O}_{5}: \mathrm{K}_{2} \mathrm{O}:: 100: 40: 40 \mathrm{~kg} / \mathrm{ha},(4) \mathrm{T}_{4}$ : $\mathrm{N}: \mathrm{P}_{2} \mathrm{O}_{5}: \mathrm{K}_{2} \mathrm{O}:: 60: 40: 40 \mathrm{~kg} / \mathrm{ha}+$ Jute leaf manure (JLM $1.0 \mathrm{t} / \mathrm{ha}),(5) \mathrm{T}_{5}: \mathrm{N}: \mathrm{P}_{2} \mathrm{O}_{5}: \mathrm{K}_{2} \mathrm{O}:: 60: 40: 40 \mathrm{~kg} / \mathrm{ha}+\mathrm{JLM} 0.5$ t/ha (6) $\mathrm{T}_{6}: \mathrm{N}: \mathrm{P}_{2} \mathrm{O}_{5}: \mathrm{K}_{2} \mathrm{O}:: 60: 40: 40 \mathrm{~kg} / \mathrm{ha}+$ Neem cake (NK) $0.5 \mathrm{t} / \mathrm{ha},(7) \mathrm{T}_{7}: \mathrm{N}: \mathrm{P}_{2} \mathrm{O}_{5}: \mathrm{K}_{2} \mathrm{O}:: 60: 40: 40 \mathrm{~kg} / \mathrm{ha}+$ NK 0.2t/ha.(8) $\mathrm{T}_{8}: \mathrm{N}: \mathrm{P}_{2} \mathrm{O}_{5}: \mathrm{K}_{2} \mathrm{O}:: 60: 40: 40 \mathrm{~kg} / \mathrm{ha}+$ bone meal (BM) 0.5 t/ha, (9) $\mathrm{T}_{9}: \mathrm{N}: \mathrm{P}_{2} \mathrm{O}_{5}: \mathrm{K}_{2} \mathrm{O}:: 60: 40: 40 \mathrm{~kg} /$ ha + BM $1.0 \mathrm{t} /$ ha. The individual plot size was $3 \mathrm{~m} \times 3$ $\mathrm{m}$ each. The ridges were made manually by spade of $15 \mathrm{~cm}$ height and $50 \mathrm{~cm}$ base width. Drainage channels were made using channels between blocks.

Jute seeds were sown during mid-August in welldrained soil and about forty days old jute seedlings (CV: JRO-204, Suren) were transplanted on fourth week of September on ridges of fertilised soils. Intercultural operation and irrigation (one to two only) were applied as and when required. Plant protection measures were taken as per standard protocol. Before harvest of the crop, biometric observations were taken from 10 matured plants selected randomly from each plot and mean was taken for comparison. The plants were threshed manually and seeds were dried properly in sun up to $8 \%$ moisture content. The seed was harvested on maturity (166 to169 DAS) in the fourth week of January. The data was analyzed following standard statistical methods.

\section{RESULTS AND DISCUSSION}

\section{Plant height of jute crop at maturity as affected by different integrated nutrient management}

The treatment $\mathrm{T}_{8}: \mathrm{N}: \mathrm{P}_{2} \mathrm{O}_{5}: \mathrm{K}_{2} \mathrm{O}:: 60: 40: 40 \mathrm{~kg} / \mathrm{ha}$ $(\mathrm{RDF})+$ bone meal $0.5 \mathrm{t} / \mathrm{ha}$ recorded the maximum plant height $(79.0 \mathrm{~cm}$, pooled, $15.8 \%$ higher over control i.e. RDF) as compared to other integrated nutrient management options and this treatment was statistically at par with the treatments $\mathrm{T}_{3}$ : $\left(\mathrm{N}: \mathrm{P}_{2} \mathrm{O}_{5}: \mathrm{K}_{2} \mathrm{O}:: 100: 40: 40 \mathrm{~kg} / \mathrm{ha}\right)$ and $\mathrm{T}_{9}(\mathrm{RDF}+$ bone meal $1.0 \mathrm{t} / \mathrm{ha}$ )(Table 2). The higher plant heights were primarily attributed due to balanced nutrition for combining of bone meal with recommended doses of chemical fertilisers for jute seed crop. Nitrogen fertilization has significant impact in regulating of plant height of jute (Maity et al., 1989).

\section{Basal diameter of jute at maturity as affected by different nutrient management}

In terms of pooled value, treatments $T_{8}(R D F+$ bone meal $0.5 \mathrm{t} / \mathrm{ha})$ and $\mathrm{T}_{9}(\mathrm{RDF}+$ bone meal $1.0 \mathrm{t} /$ ha) recorded higher basal diameters $(1.03 \& 1.02 \mathrm{~cm}$ respectively) than the other nutrient management practices (18.6 to $19.8 \%$ higher over control) did. But they did not vary significantly amongst themselves (Table 2). The higher basal diameter of jute plants is accounted primarily for balanced nutrition, with chemical nutrients integrated with bone meal which supplied additional amounts of major and minor nutrients.

\section{Number of branches/plant of jute at maturity as affected by different integrated nutrient management}

Number of branch/plant is considered as one of the most important yield attributing parameters of jute, as higher branch/plant is linearly correlated with the higher number of pod production. Integrated nutrient management practice $\mathrm{T}_{9}$ i.e. $\mathrm{RDF}+$ bone meal $1.0 \mathrm{t} / \mathrm{ha}$ recorded the highest number of branches per plant (4.37, pooled, $73 \%$ higher over control, RDF) and it was statistically at par with treatments $\mathrm{T}_{8}$ (4.27), $\mathrm{T}_{4}(4.22)$ and $\mathrm{T}_{2}$ (3.97). The 
reason behind such higher numbers of branches may be due to balanced nutrition through RDF and bone meal as compared to other integrated nutrient management practices.

Table 1: Weather report of during jute seed production in experimental field

\begin{tabular}{|c|c|c|c|c|c|}
\hline Year & & & Rainfall & Max. & Max. \\
\hline 2012 & $\begin{array}{c}\text { Temp. } \\
\left({ }^{\circ} \mathrm{C}\right)\end{array}$ & $\begin{array}{c}\text { Temp. } \\
\left({ }^{\circ} \mathrm{C}\right)\end{array}$ & & & \\
\hline September & 31.96 & 25.06 & 302.0 & 93.63 & 76.56 \\
\hline October & 31.50 & 21.57 & 129.8 & 91.61 & 62.12 \\
\hline November & 28.52 & 17.75 & 44.8 & 92.70 & 52.76 \\
\hline December & 24.79 & 17.22 & 9.4 & 96.38 & 56.41 \\
\hline \multicolumn{6}{|l|}{2013} \\
\hline January & 23.86 & 10.48 & 0.0 & 95.67 & 46.38 \\
\hline September & 32.87 & 26.18 & 127.4 & 95.00 & 67.66 \\
\hline October & 29.88 & 24.02 & 388.0 & 96.30 & 80.06 \\
\hline November & 28.78 & 16.95 & 0.0 & 93.70 & 52.90 \\
\hline December & 26.08 & 13.07 & 0.0 & 97.87 & 54.16 \\
\hline \multicolumn{6}{|l|}{2014} \\
\hline January & 23.41 & 11.33 & 0.00 & 98.25 & 57.58 \\
\hline
\end{tabular}

Number of pods/plant of jute at maturity as affected by different nutrient management practices

Treatment $\mathrm{T}_{9}$ i.e. $\mathrm{RDF}+$ bone meal $1.0 \mathrm{t} /$ ha recorded the highest number of pods per plant (29.98, pooled, $47.7 \%$ higher over control) followed by treatment $\mathrm{T}_{8}$ (29.65, pooled, $46 \%$ higher over control) and treatment $\mathrm{T}_{2}: \mathrm{N}: \mathrm{P}_{2} \mathrm{O}_{5}: \mathrm{K}_{2} \mathrm{O}:: 80: 40: 40 \mathrm{~kg} / \mathrm{ha}(26.63$, pooled, $31.2 \%$ higher over control). Higher number of pods/plant in treatment $\mathrm{T}_{8}$ and $\mathrm{T}_{9}$ were primarily achieved due to balanced nutrition (both macro and micro) by bone meal with recommended doses of fertilisers (RDF). Saha et al. 2014 also reported that yield attributes i.e. no. of pods per plant, no. of seeds per pod, 1000 seed weight and seed yield significantly increased with the increasing irrigation level ( $\Psi_{\alpha}=-0.03 \mathrm{Mpa}$ at $30 \mathrm{~cm}$ soil depth) and nitrogen dose (40 kg nitrogen/ha).

\section{Seed yield of jute as affected by different integrated nutrient management practices}

Jute seed production was the highest with $\mathrm{N}: \mathrm{P}_{2} \mathrm{O}_{5}: \mathrm{K}_{2} \mathrm{O}:: 60: 40: 40 \mathrm{~kg} / \mathrm{ha}(\mathrm{RDF})$ with bone meal 1.0 $\mathrm{t} / \mathrm{ha}\left(\mathrm{T}_{9}\right)$ i.e., $635.83 \mathrm{~kg} / \mathrm{ha}(23 \%$ more over control) followed by treatment $\mathrm{T}_{8}$ : RDF + bone meal $0.5 \mathrm{t} /$ ha $(611.67 \mathrm{~kg} / \mathrm{ha})$, which were significantly higher than rest all other treatments (Table 2). In control (RDF) the jute seed production potential was only $518.33 \mathrm{~kg} / \mathrm{ha}$. The RDF along with jute leaf manure @ 1.0 t/ha produced $545.83 \mathrm{Kg}$ jute seed/ha (5\% more over control). Combination of recommended dose of fertilisers and Neem cake@ 0.2 t/ha produced $580 \mathrm{~kg}$ jute seed/ha (11.89\% more over control). Amongst the different nutrient management options, treatment $\mathrm{T}_{9}(\mathrm{RDF}+$ bone meal $1.0 \mathrm{t} / \mathrm{ha}$ ) recorded the highest growth attributes like basal diameter, as well as yield attributes. Augmented fertiliser treatment $\mathrm{T}_{3}: \mathrm{N}: \mathrm{P}_{2} \mathrm{O}_{5}: \mathrm{K}_{2} \mathrm{O}:: 100: 40: 40 \mathrm{~kg} / \mathrm{ha}$ alone recorded the highest jute seed yield (579.17, pooled). Saha et al. (2014) also reported beneficial effect of irrigation and $\mathrm{N}$ fertilization on growth and yield of jute. Mandal et al. (2015) reported integrated application of $75 \%$ RDF $25 \% \mathrm{~N}$ from FYM proved best results not only in influencing maximum growth and seed yield but also in maintaining soil nutrient status.

The mechanism behind the higher seed yield in INM practices may be due to protracted release of nutrients from applied chemical fertilisers.

Jute seed yield in the second year is not proportionately high as compare to that of first year in spite of its higher yield attributes (no of branches/ plant, no of pods/ plant) primarily due to no rainfall (54.2 mm in November and December 2012, Table 1) which exposed the jute seed crop to moisture stress at pod development and maturity stage.

\section{Economics of jute seed production as influenced by different integratednutrient managements}

The economics presented in Table 3 indicates mean gross return of ₹ 95375/ha was recorded from treatment $\mathrm{T}_{9^{\prime}}$ (RDF + bone meal @ $1.0 \mathrm{t} / \mathrm{ha}$ ), which was mainly attributed to its higher seed production/

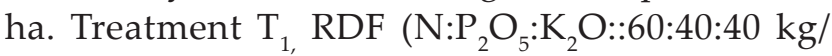
ha) recorded the lowest mean gross return (₹ $77750 /$ ha) due to its poor productivity under this fertilization practice. Cost of seed production were lower ( $₹ 51800$ to $₹ 53800 /$ ha) in chemical fertiliser treatments alone in $\mathrm{T}_{2}$ and $\mathrm{T}_{3}$. Treatment $\mathrm{T}_{5^{\prime}}, \mathrm{RDF}+$ jute leaf manure @ $0.5 \mathrm{t} / \mathrm{h}$ a recorded lower total cost ( $₹ 51000$ to $₹ 51400 /$ ha) owing to its zero cost involvement in jute leaf manure and its gross returns ranged from ₹ 80000/ha-₹ 82500/ha. In both the years, highest cost of seed production were 


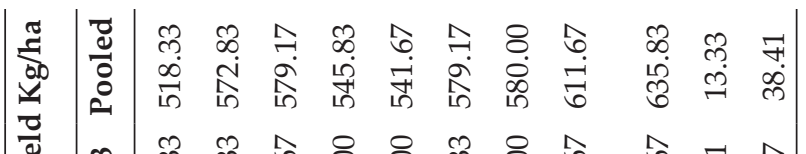

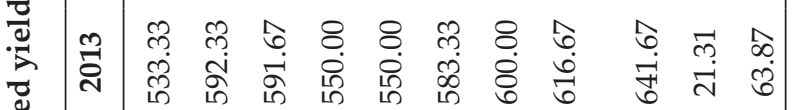

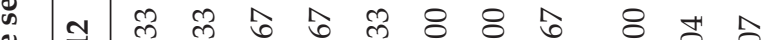

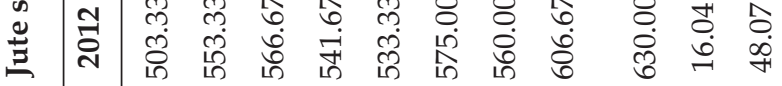

च ప बे

ब

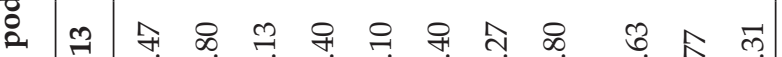

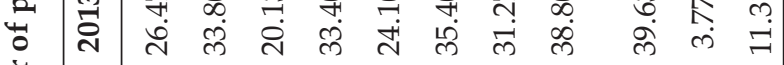

ป

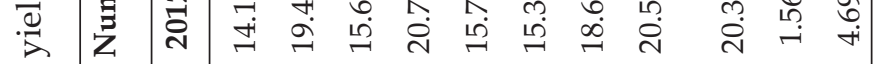

ఖ

.

ฮ

㕝

胥

$\frac{\pi}{\pi}$

은

ठृ

$\stackrel{Ð}{.}$

范

อุ.

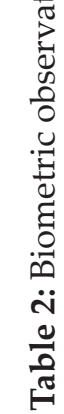

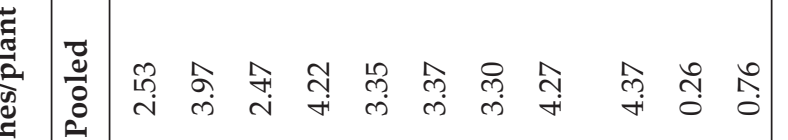

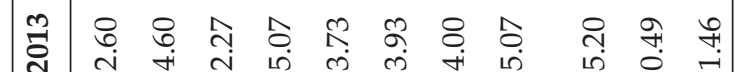

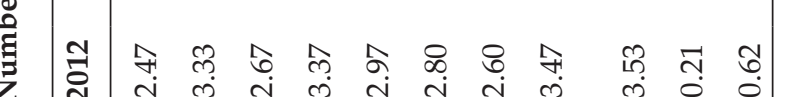

हี छ

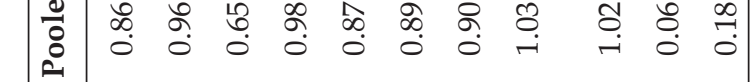

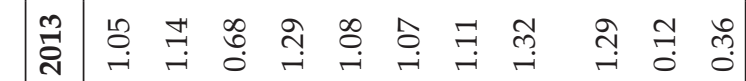

苞

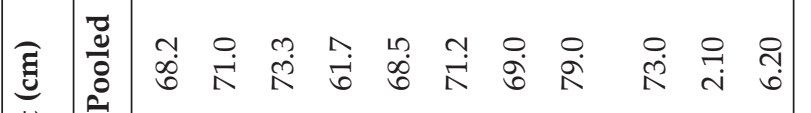

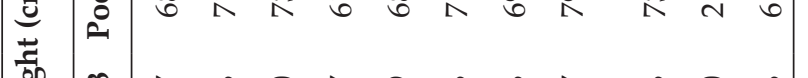

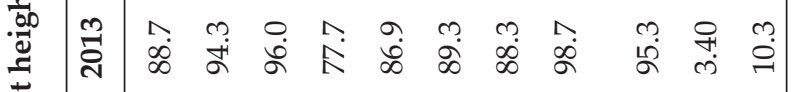

萦

离

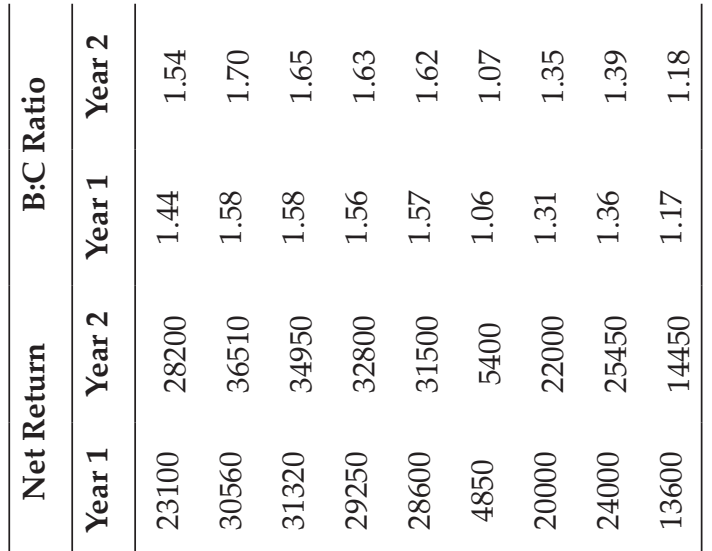

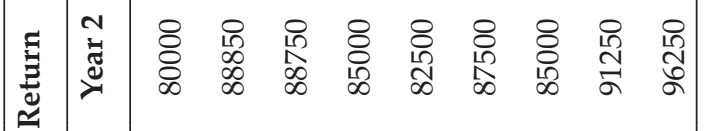

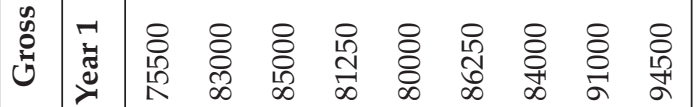

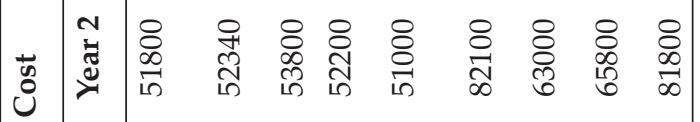

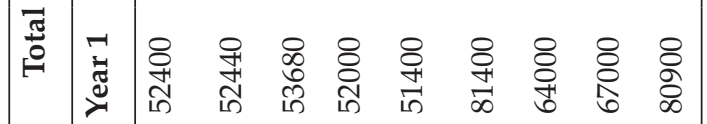

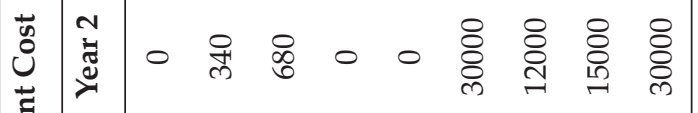

吾

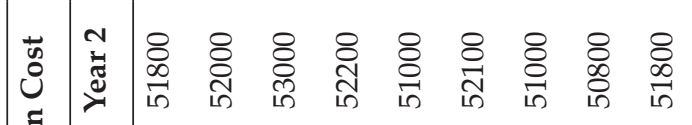

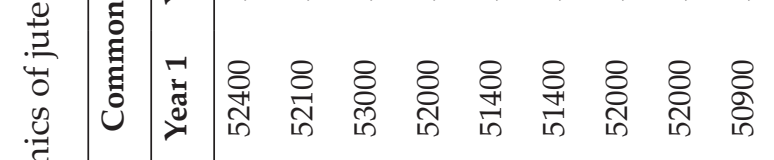

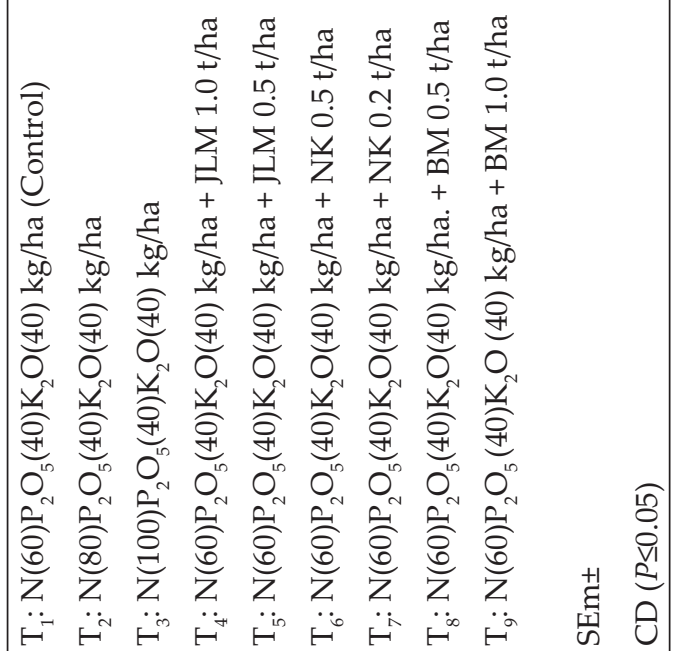

$\ddot{m}$
$\ddot{0}$
$\ddot{0}$
$\ddot{\pi}$

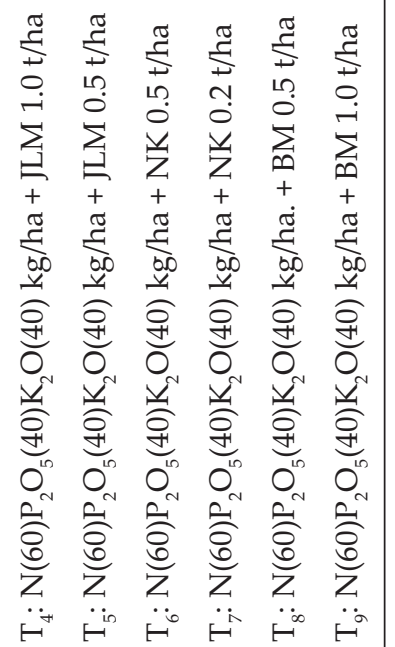


recorded from treatment $\mathrm{T}_{6}(\mathrm{RDF}+$ neem cake 0.5 $\mathrm{t} / \mathrm{ha}$ ) and treatment $\mathrm{T}_{9}(\mathrm{RDF}+$ bone meal $1.0 \mathrm{t} / \mathrm{ha})$ which were primarily due to higher individual cost of bone meal and neem cakes. Augmented fertiliser treatment $\mathrm{T}_{2}\left(\mathrm{~N}: \mathrm{P}_{2} \mathrm{O}_{5}: \mathrm{K}_{2} \mathrm{O}:: 80: 40: 40 \mathrm{~kg} / \mathrm{ha}\right)$ recorded higher net returns (₹ 30560 to $₹ 36510 /$ ha) owing to its low cost of production. RDF+ jute leaf manures @ 0.5 to $1.0 \mathrm{t} /$ ha recorded higher net returns (₹ 28600 to ₹ $29250 /$ ha) owing to its low cost of production and relatively higher seed yield over RDF alone in both years. Treatment $\mathrm{T}_{6}$ (RDF + neem cake $0.5 \mathrm{t}$ / ha) recorded the lowest net return of ₹ 4850/ha in the first year and ₹ 5400/ha in the second year. The highest $\mathrm{B}$ : $\mathrm{C}$ ratio, 1.58 to 1.70 was recorded from treatment $\mathrm{T}_{2^{\prime}}\left(\mathrm{N}: \mathrm{P}_{2} \mathrm{O}_{5}: \mathrm{K}_{2} \mathrm{O}:: 80: 40: 40 \mathrm{~kg} / \mathrm{ha}\right)$ and followed by treatment $\mathrm{T}_{3^{\prime}} \mathrm{N}: \mathrm{P}_{2} \mathrm{O}_{5}: \mathrm{K}_{2} \mathrm{O}:: 100: 40: 40 \mathrm{~kg} /$ ha. RDF + jute leaf manures @ 0.5 to $1.0 \mathrm{t} / \mathrm{ha}$ also recorded relatively higher $\mathrm{B}: \mathrm{C}$ ratio over $\mathrm{RDF}+\mathrm{Bone}$ meal and RDF + neem cakes at their doses applied.

\section{CONCLUSION}

The results convincingly indicates that recommended dose of NPK in combination with bone meal has proved to be most important integrated nutrient management practice for achieving higher productivity in traditional jute growing areas of Eastern India specially in West Bengal.

\section{REFERENCES}

Ghorai, A.K., Chowdhury and A.K. Chakraborty 2008. Home scale jute seed production for self-sufficiency. Jaf. News, 6(2): 15.

Maity, P.K., Palchawdhury, P., Mandal, B.K. and Dasmahapatra, A.N. 1989. Effect of different sources and levels of nitrogen on jute (Corchorus olitorius L. and C. capsularis L.) Jute Development Journal, 9(1): 31-35.

Malik, G.C., Banerjee, M. and Shankar, T. 2013. Feasibility and economic viability of jute seed production in lower Gangetic plains of West Bengal. SATSA Mukhaptra Annual Technical Issue, 17: 120-126.

Mandal, P., Mondal, S.S. and Patra, B.C. 2015. Effect of Integrated Nutrient Management on Seed Production of Olitorius Jute Raised from Top Cutting Method. International Journal of Bio-resource and Stress Management, 6(1): 98-101.

Saha, D., Zaman, A. and Gunri, S.K. 2014. Effect of various levels of irrigation and nitrogen doses on growth and seed production of jute in West Bengal. Journal of Interacademicia, 18(2): 185-189. 
